\title{
The management and financial implications of variable responses to grapevine leafroll disease
}

\author{
Vaughn A. Bell ${ }^{1}$ (D) Philip J. Lester ${ }^{2} \cdot$ Gerhard Pietersen $^{3} \cdot$ Alistair J. Hall $^{4}$
}

Received: 22 June 2020 / Accepted: 29 December 2020

(C) Società Italiana di Patologia Vegetale (S.I.Pa.V.) 2021

\begin{abstract}
Grapevine leafroll-associated virus 3 (GLRaV-3) is a worldwide pathogen of Vitis negatively affecting wine production. In red berry cultivars grown in New Zealand, the foliar changes to GLRaV-3-infected vines inform decisions on vine removal (roguing). However, roguing does not always contain GLRaV-3 spread in the presence of an insect vector like the mealybug, Pseudococcus calceolariae. Virus incidence and mealybug abundance data collected annually over 7 years were modelled under differing scenarios to ascertain support for roguing. In a simulated 1 ha vineyard planted in 2500 mature Merlot vines, simulations over 20 years evaluated the effectiveness of roguing, 'rogue $1+2$ ' (concurrent roguing of symptomatic plus both within-row neighbouring vines), inefficient roguing (50\% of symptomatic vines rogued), and 'no-action'. The model used variable initial GLRaV-3 incidence $(0.4,5,10,15$ and 20\%), and low, median and high vector densities (6, 26 and 75 mealybugs per 100 vine leaves, respectively). Roguing was the optimal response to GLRaV-3, independent of the initial incidence, but results were vector density dependent. At a low vector density, roguing relative to the other responses tested, sustained the lowest annual GLRaV-3 incidence, the least need to plant replacement vines and the lowest estimated average annual costs plus loss of income. At median and high vector densities, roguing remained the most favourable response but virus control was less effective and the costs incurred were higher. Thus, for vineyards affected by GLRaV-3, achieving economic sustainability relies on integrating efficient roguing with effective vector management.
\end{abstract}

Keywords GLRaV-3 · Roguing $\cdot$ Mealybugs $\cdot$ Pseudococcus calceolariae

\section{Introduction}

Grapevine leafroll-associated virus 3 (GLRaV-3) is an economically damaging viral pathogen of grapevines with a worldwide distribution (Almeida et al. 2013). The potential for GLRaV-3 to negatively alter wine quality has seen New Zealand Winegrowers, the national industry body, invest in

Vaughn A. Bell

Vaughn.Bell@plantandfood.co.nz

1 The New Zealand Institute for Plant and Food Research Limited, Private Bag 1401, Havelock North 4157, New Zealand

2 School of Biological Sciences, Victoria University of Wellington, $\mathrm{P}$ O Box 600, Wellington 6012, New Zealand

3 Department of Genetics, Stellenbosch University, Stellenbosch 7600, South Africa

4 The New Zealand Institute for Plant and Food Research Limited, Private Bag 11-030, Palmerston North 4442, New Zealand research prioritising in-vineyard management (Andrew et al. 2015). Unlike asymptomatic white berry cultivars (Maree et al. 2013), GLRaV-3-infected vines among red berry cultivars undergo late-season changes to leaf colour and morphology (Golino et al. 2002). Visual diagnostics is a reliable predictor of GLRaV-3, with evidence of good sensitivity and specificity relative to serological testing (Bell et al. 2017). Consequently, vineyard owners in South Africa (Pietersen et al. 2013, 2017) and New Zealand (Bell et al. 2018) remove vines visually diagnosed with foliar symptoms of GLRaV-3 in a process known as roguing.

In New Zealand, research on GLRaV-3 management by roguing was undertaken in 13 commercial vineyards from 2009 to 2015 (Bell et al. 2018). Each vineyard was planted in one of five red berry cultivars, where in 2009 , baseline incidence ranged from $4 \%$ to $24 \%$. Visual symptom identification was used annually for the next 6 years to assess GLRaV-3 incidence and identify vines for roguing. During this time, pre-harvest inspections of vine leaves enabled absolute counts of the mealybug Pseudococcus calceolariae, the most common GLRaV-3 vector 
found (Petersen and Charles 1997; Bell et al. 2018). The spread of GLRaV-3 observed over time was overwhelmingly along vine rows, with the immediate within-row neighbours (referred to as 'first' vines) most at risk of infection. However, despite this pattern of vector-mediated spread, annual roguing steadily reduced the virus risk: in 2010, an average of $26 \%$ of first vines were GLRaV-3 symptomatic; by 2015 , that reduced to just $6 \%$ (Bell et al. 2018).

From these data, it was recommended owners 'rogue' symptomatic vines only, implement a robust vector management programme and when planting, they use vines certified GLRaV-3-free under the Grafted Grapevine Standard (Andrew et al. 2015). Thus, by adopting an integrated response, some owners reduced GLRaV-3 incidence to $<1 \%$ by 2012 , where it was sustained until data collection for the study ceased in 2015 (Bell et al. 2018).

Despite annual roguing in several other study vineyards, however, GLRaV-3 incidence was consistently $>1 \%$ (Bell et al. 2018). Because of this result, which was attributed to poor vector management, we considered that where high mealybug vector density co-occurred with moderate to high virus incidence, an alternative management response may be required. Thus, in view of the increased risk of vectormediated GLRaV-3 transmission to first vines, roguing both these vines plus the symptomatic vine concurrently, had been proposed. This so-called 'rogue $1+2$ ' response was a preemptive measure targeting potential latent first vine infections. Despite the adoption of rogue $1+2$ in a few vineyards not part of the Bell et al. (2018) study, the idea was never widely promulgated in New Zealand because of a lack of analyses supporting effectiveness and economic feasibility.

When considering the issue of GLRaV-3 management in New Zealand, we looked to earlier theoretical work on disease control by roguing, and how different scenarios and management responses influenced outcomes. Critical in this regard was the seminal work of Sisterson and Stenger (2013) whose insights informed our decision to further analyse the virus and vector data of Bell et al. (2018). By modelling real data collected over 7 years, our objective was to determine if there were combinations of virus incidence and mealybug vector densities that might warrant modifying the roguing response. We used three different mealybug vector densities (low, median and high) to assess the management outcomes and cost-effectiveness of roguing, rogue $1+2$, inefficient roguing, and a 'no-action' decision to aid in the development of an integrated response to GLRaV-3.

\section{Materials and methods}

All statistical analyses and simulations were carried out using SAS v.9.4 of the SAS System for Windows (Copyright (C)2008, SAS Institute Inc., Cary, NC).
The starting point: a published model The starting point for this work was the theoretical research of Sisterson and Stenger (2013), who used a model of disease spread to compare the consequences of either taking no action, or roguing and replacing different proportions of infected trees or vines in a vineyard. In their model, new plant infections could be caused by either (i) "primary" infection, which could come from external sources such as infection in neighbouring vineyards, or (ii) "secondary" infection, where infection was transmitted (by insect vectors) from infected plants in any one of eight neighbouring plant positions. They demonstrated that the model could predict how total crop yield and numbers of plants removed and replanted over 25 years would depend on: the rates of primary and secondary infections; the proportion of infected plants rogued and replaced; the yield of infected plants relative to uninfected plants; and the time from replanting until plants reach full production.

As a first step in developing the current model, we implemented the single farm model of Sisterson and Stenger (2013), and confirmed we could replicate their model and predictions.

A more realistic model of virus spread The work of Bell et al. (2018) showed that secondary spread of leafroll virus was more complex process. Thus, these authors categorised neighbouring vines into four positions (Fig. 1), and found that uninfected vines that had previously had an infected vine in relative position $\mathrm{F}$ ('First') were the most likely to become infected in subsequent years. There were successively smaller probabilities of infection for vines where the nearest previously infected vine had been in positions $S$ ('Second'), O ('Opposite'), and D ('Diagonal'). Vines that had no previously

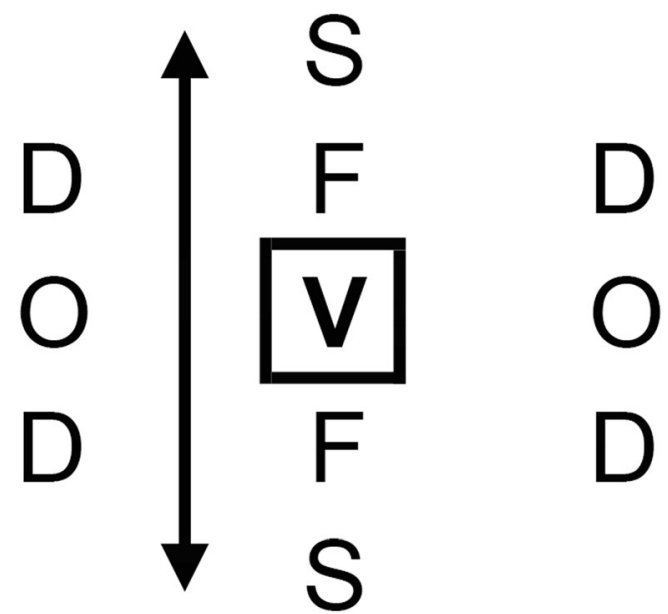

Fig. 1 A diagrammatic view of three vine rows showing the position of the 10 nearest neighbour vines relative to a grapevine leafroll-associated virus 3 symptomatic vine (V). There were four nearest neighbour positions: within-row 'first' (F) and 'second' (S) vines; across-row 'opposite' (O) and 'diagonal' (D) vines. Row width was $2.4 \mathrm{~m}$; vines within a row were separated by $1.8 \mathrm{~m}$ (simulated vineyard dimensions, $45 \mathrm{~m} \times 223 \mathrm{~m}$ ). Black arrow denotes row direction. After Bell et al. (2018) 
infected vines in any of these neighbouring positions had the lowest probability of infection.

We therefore extended the Sisterson and Stenger (2013) model to allow different probabilities of infection from neighbours in different positions, estimating model parameters from the data of Bell et al. (2018). Generalising the approach of Sisterson and Stenger (2013) to more than one category of neighbour, we modelled the probability of any currently uninfected vine becoming infected in the following year $(P)$ as being dependent on the infection status of neighbouring vines, and the probability of infection from other sources, using

$P=1-\left(1-P_{e}\right) \prod_{i}\left(1-P_{i}\right)^{n_{i}}$

where $P_{e}$ is the probability of infection from other sources ("elsewhere"), $n_{i}$ the number of infected vines in category $i$ ( $i=\mathrm{F}, \mathrm{S}, \mathrm{O}, \mathrm{D})$, and $P_{i}$ is the probability that a single infected vine in category $i$ will lead to infection of the target vine in the coming year. This equation takes into account the fact that once a vine has been infected from one source, further infection from other sources has no effect. This ensures that the probability of infection can never exceed 1 , even though when small it is approximately the sum of the probabilities of infection from all sources (note: we estimated the interval between initial GLRaV-3 infection in a vine and the appearance of foliar symptoms, or the latent period, to be about 12 months).

In many New Zealand vineyards, GLRaV-3 is transmitted vine to vine by the mealybugs, $P$. calceolariae or $P$. longispinus (Petersen and Charles 1997). Hence, the probability of infection from any source must scale proportionally to the relative vector density. To take this into account, the equation is modified to become

$P=1-\left[\left(1-P_{e}\right) \prod_{i}\left(1-P_{i}\right)^{n_{i}}\right]^{r(o, y)}$

where $r(o, y)$ is the relative vector density in the particular vineyard $(o)$ and year $(y)$.

Fitting models to data This model was fitted to all the data collected by Bell et al. (2018), with parameters fitted to maximise the likelihood of the observed data using SAS PROC NLMIXED. Data for all years were fitted together, with the same relative probabilities of infection $\left(P_{e}\right.$ and $P_{i}, i=\mathrm{F}, \mathrm{S}, \mathrm{O}$, D) fitted to all vineyards and years, but with fitted vector densities $(r(o, y))$ varying among vineyards and years. Mealybug densities were fitted relative to the average density across all vineyards and years considered, which was set to be one.

We considered the four categories of neighbours identified by Bell et al. (2018), initially making predictions for the following year based on the infection status of the neighbouring vines in the current year. The fitted model was consistent with the findings of Bell et al. (2018) that the most likely source of infection was an infected vine in position $\mathrm{F}\left(P_{1}=0.148\right)$, with successively smaller probabilities of infection from infected vines in positions $\mathrm{S}\left(P_{2}=0.041\right), \mathrm{O}\left(P_{3}=0.022\right)$, and D $\left(P_{4}=\right.$ 0.019).

Bell et al. (2018) considered that the presence of infected neighbouring vines in previous years could also increase the probability that a currently uninfected vine would be infected in the coming year. We therefore also considered models in which the probability of vine infection in the coming year was dependent on not only the infection status of neighbouring vines in the current year, but also on their infection status 1 or 2 years earlier. Of course, as the number of years used for prediction increased, the number of vineyard-year combinations that could be used to fit the model reduced: there were 59 vineyard-year combinations for which data were available for both that year and in the following year (i.e. the infection status of all vines was recorded in two successive years); 45 of these were also monitored in the previous year (i.e. recorded in three successive years); and for only 32 were monitored in both the previous 2 years (i.e. recorded in four successive years in total).

Model Selection We used the Akaike Information Criterion (AIC) to compare models including different numbers of years of historical data. A model predicting the probability of vine infection in the coming year based on the infection status of neighbouring vines in the current and one previous year was chosen, because this model (AIC $=18,183$ ) performed better than a model based on the current year's data alone (AIC = 18,488 ) when both models were fitted to the 45 year-vineyard combinations available for fitting models including one previous year. Moreover, this model $(\mathrm{AIC}=12,146)$ also performed better than a model including vine infection status from two previous years $(\mathrm{AIC}=12,245)$ when both models were fitted to the 32 year-vineyard combinations available for fitting models including two previous years.

When the model based on the infection status of neighbouring vines in the current and previous year was fitted to the data, fitted probabilities relating positions $\mathrm{O}$ and $\mathrm{D}$ were very similar, so the fitting process was constrained to ensure that the effect of a more distant infected vine (position D) was no greater than the effect of a closer infected vine (position $\mathrm{O}$ ) in either year. The fitted average probabilities that a vine will be infected in the coming year, given one infected neighbour in each position in either the current or previous year, are shown in Table 1. Position $\mathrm{V}$ is the current vine position, so the probability of zero indicates that no newly planted vines became symptomatic in the first year, even if an infected vine was present then rogued in the previous year.

The highest probability of a new infection in the coming year being spread from a single neighbouring vine is if that vine is in position $\mathrm{F}$ in the current year. A currently infected 
Table 1 Average probabilities that a grapevine will become newly infected with grapevine leafroll-associated virus 3 (GLRaV-3) due to a neighbouring vine in one of the positions ('first', 'second', 'opposite', 'diagonal') in either the current or previous year. The zero probability given for position $\mathrm{V}$ in the previous year reflects the fact that no newly planted vines (following roguing of an infected vine in the same position in the previous year) showed foliar symptoms of GLRaV-3

\begin{tabular}{|c|c|c|c|c|c|c|c|c|c|c|}
\hline \multirow[b]{2}{*}{ Position } & \multicolumn{4}{|c|}{ Current year } & \multicolumn{5}{|c|}{ Previous year } & \multirow[b]{2}{*}{ Random $\left(P_{e}\right)$} \\
\hline & $\mathrm{F} \S$ & $\mathrm{S}$ & $\mathrm{O}$ & $\mathrm{D}$ & $\mathrm{V}$ & $\mathrm{F}$ & $\mathrm{S}$ & $\mathrm{O}$ & $\mathrm{D}$ & \\
\hline Average infection probability & 0.142 & 0.038 & 0.016 & 0.016 & 0.000 & 0.020 & 0.008 & 0.007 & 0.007 & 0.010 \\
\hline$\%$ of current year, position $\mathrm{F}$ & 100 & 27 & 11 & 11 & 0 & 14 & 5 & 5 & 5 & 7 \\
\hline
\end{tabular}

${ }^{\S}$ Nearest neighbour positions: $\mathrm{F}=$ 'first', $\mathrm{S}=$ 'second', $\mathrm{O}=$ 'opposite', $\mathrm{D}=$ = 'diagonal', $\mathrm{V}=\mathrm{GLRaV}-3$-infected vine

vine in position $\mathrm{S}$ in the current year is the next most likely source of a new infection ( $27 \%$ as likely), followed by an infected vine in position $\mathrm{F}$ the previous year (14\%). The probability of a new infection arising from a single neighbour in any one of these positions is higher than the fitted average probability of infection from any other source not considered in the model $\left(P_{e}=0.010\right)$.

The probabilities presented in Table 1 are for the average infestation level of the 45 year-vineyard combinations considered here. Probabilities for low, median, and high mealybug vector densities (Table 2) are presented in Supplementary Table 1 . The probability of infection from neighbouring vines in all positions increases with increasing vector density, but for the range of vector densities considered here the relative ranking of the infection probabilities from infected vines in different relative positions changes only slightly.

Costs associated with managing leafroll virus Initial estimates of costs related to managing GLRaV-3 were obtained from Nimmo-Bell and Company Limited (2006) and unpublished data and/or information supplied by New Zealand Winegrowers and experienced viticulturists. These costs were expressed as percentages of crop value or of total yield, and loss of crop value per tonne harvested (Table 2).

If infected vines are present in the vineyard, these infections will potentially affect income in two ways: by reducing yield, and (if GLRaV-3 incidence is too high) by negatively influencing the value (per tonne) of the crop. In the USA, a socalled virus 'quality penalty' was applied to economic analyses for vineyards in New York (Atallah et al. 2012) and California (Ricketts et al. 2015). In the latter study, the assumed $10 \%$ quality penalty was deemed inadequate based on survey respondents noting that poor quality fruit had potential to cost them annual contracts, discourage contract renewal, and damage relationships with buyers, winemakers and customers (Ricketts et al. 2015). Thus, based on overseas trends, and following Nimmo-Bell and Company Limited (2006), we assumed that yield declined progressively following infection between 1 and 4 years; and the value received for the harvested crop was financially penalised at an incidence of
$12.5 \%$ or more (Table 2). These values were 'on average' estimates.

If the infection in the vineyard was managed by roguing and planting replacement healthy vines, then costs were incurred, which when comparing management responses, needed to be balanced against the costs of leaving infected vines in situ. The estimated costs of roguing, planting, and vine trainings are listed in Table 2. Additional costs were incurred because it was assumed newly planted vines took 5 years to reach full production (Table 2).

When comparing management responses, we calculated the total cost of having infected vines present in the vineyard, plus the costs of management, including vine removal, replanting, and loss of yield of young vines (Table 2). An assumed value of virus-free Merlot fruit at harvest is presented in Table 2.

Model Simulations We used a standard vineyard of approximately 1 ha planted with 2500 mature Merlot vines arranged in 20 rows, each with 125 vines. Within this vineyard we simulated the spread of GLRaV-3, applying the model described above with relative probabilities of infection from neighbouring infected vines as in Table 1. Random simulations of 200 such standard vineyards were run over 20 years, using three different relative mealybug vector densities (infestations) from Bell et al. (2018), a range of different initial GLRaV-3 incidence in the vineyards to a maximum of $20 \%$, and five different management responses (Table 2).

In total, 15,000 simulations of vineyards were carried out (i.e. three levels of vector density $x$ five initial GLRaV-3 incidence scenarios $x$ five management responses $\times 200$ simulations each), each tracking the fate of 2500 vines over 20 years.

For each simulation, we recorded the numbers of infected vines per year, and the numbers of vines removed and replanted per year. From this, and the cost information above, we calculated average annual costs plus loss of income over 20 years for each management response considered, and hence compared and contrasted the management and financial outcomes of each response in different situations. 
Table 2 Terms and definitions applicable to the grapevine leafroll-associated virus 3 (GLRaV-3) management response as assumed and applied in the model. Monetary values are NZ dollars

\begin{tabular}{|c|c|}
\hline Term & Definition \\
\hline Value of Merlot fruit at harvest & $\begin{array}{l}\text { Assumed at } \$ 12,600 \text { per hectare (i.e. } 7 \mathrm{t} \text { per hectare at } \$ 1800 / \mathrm{t} \text { ) to reflect } \\
\text { the absence of GLRaV-3 or any GLRaV-3-related management costs }\end{array}$ \\
\hline Costs of GLRaV-3: roguing and planting & $\begin{array}{l}\$ 12.50 \text { made up of } \$ 4 \text { for vine removal, } \$ 5.50 \text { for new vine, } \$ 2 \text { planting } \\
\text { and } \$ 1 \text { vine training }\end{array}$ \\
\hline Costs of GLRaV-3: yield loss due to infected vine & $10,20,40 \& 50 \%$ yield loss in years, $1,2,3 \& 4$, respectively \\
\hline Costs of GLRaV-3: lost crop value (per tonne harvested) & $\begin{array}{l}\text { Loss of crop value of } 0 \% \text { (at } 0 \text { to } 12.5 \% \text { GLRaV-3 incidence), } 5 \% \\
\quad(12.5 \text { to } 25 \%), 25 \% \text { (25 to } 50 \%) \& 50 \% \text { (50 to } 100 \%)\end{array}$ \\
\hline $\begin{array}{l}\text { Costs of GLRaV-3: loss of yield from a replacement } \\
\text { virus-free vine } \\
\text { Mealybug vector densities: }\end{array}$ & Yield of $0,0,60,90 \& 100 \%$ in years $1,2,3,4 \& 5$, respectively \\
\hline Low & $\begin{array}{l}\text { Approximate 20th percentile of relative mealybug vector density; } \\
\text { six mealybugs per } 100 \text { vine leaves inspected or } 2 \% \text { leaf infestation. }\end{array}$ \\
\hline Median & $\begin{array}{l}\text { Approximate 50th percentile of relative mealybug vector density; } \\
26 \text { mealybugs per } 100 \text { vine leaves inspected or } 7 \% \text { leaf infestation }\end{array}$ \\
\hline High & $\begin{array}{l}\text { Approximate } 80 \text { th percentile of relative mealybug vector density; } \\
75 \text { mealybugs per } 100 \text { vine leaves inspected or } 21 \% \text { leaf infestation }\end{array}$ \\
\hline Initial GLRaV-3 incidence & $0.4,5,10,15 \& 20 \%$ \\
\hline \multicolumn{2}{|l|}{ Management responses: } \\
\hline Roguing & $\begin{array}{l}\text { Roguing all GLRaV-3-infected vines showing foliar symptoms annually } \\
\text { and then planting replacement vines annually }\end{array}$ \\
\hline Rogue $1+2$ & $\begin{array}{l}\text { Roguing and replanting not only the GLRaV-3-symptomatic vine but also } \\
\text { the adjacent within-row (or 'first') vines either side of it annually }\end{array}$ \\
\hline Rogue 50\% (inefficient roguing) & $\begin{array}{l}\text { Roguing a random } 50 \% \text { of GLRaV-3-infected vines annually and planting } \\
\text { replacement vines annually. Assumed to occur where vineyard personnel } \\
\text { were insufficiently trained to recognise GLRaV-3 symptoms and/or } \\
\text { where visual diagnostics were undertaken too early in the growing season } \\
\text { to identify all symptomatic vines in a given year }\end{array}$ \\
\hline Rogue $1+250 \%$ (inefficient roguing) & $\begin{array}{l}\text { Roguing } 1+2 \text { a random } 50 \% \text { of GLRaV-3-infected vines and the adjacent } \\
\text { vines in the same row annually and planting replacement vines annually. } \\
\text { This response was assumed to occur where vineyard personnel were } \\
\text { insufficiently trained to recognise GLRaV-3 symptoms and/or where visual } \\
\text { diagnostics were undertaken too early in the growing season to identify all } \\
\text { symptomatic (or symptomless first) vines in a given year }\end{array}$ \\
\hline No-action & A deliberate decision not to rogue any GLRaV-3-infected vines \\
\hline
\end{tabular}

Relationship between fitted relative mealybug vector densities $(r(0, y))$ and observed mealybug vector numbers The fitted relative vector densities for each vineyard and year $r(o, y)$ were compared with actual mealybug counts (average mealybugs/ leaf $\mathrm{MB}_{\mathrm{L}}$, or fraction of infested leaves $\mathrm{IL}_{\mathrm{F}}$ ) where these were available. Linear regression was carried out using log transformed data, in order to minimise variation in the residuals with the size of the predictor variable. The best fits were obtained using a weighted average of mealybug data from the current (60\% weight) and previous (40\%) years.

The slopes of the regressions of the $\log (r(o, y))$ against both $\log \left(\mathrm{MB}_{\mathrm{L}}\right)$ and $\log \left(\mathrm{IL}_{\mathrm{F}}\right)$ differed significantly from zero $(P<$ 0.001 ), showing a strong link between observed and fitted mealybug density. Also the slopes did not differ significantly from one, which means that simple proportionality between fitted relative vector densities and either average numbers of mealybugs per leaf, or fraction of infested leaves, should be a satisfactory approximation.

\section{Results}

Roguing The model showed that roguing GLRaV-3symptomatic vines at an initial low incidence $(0.4 \%)$ when mealybug density was also low, were the optimal conditions to achieve quick, efficient and cost-effective control of this insect-vectored pathogen. After removing the initial 10 virus-infected vines per hectare $(0.4 \%)$ in Year 1 , the model showed that from Year 2, roguing resulted in an average loss of just five vines $(0.2 \%)$ per year through until Year 20 (Figs. 2a and 3a). Under this low vector density and low incidence scenario, the estimated average annual costs plus loss of 
income was NZ\$131 per hectare (Table 3). Of this cost, $84 \%$ was directly attributed to roguing and yield loss from replacement young vines.

At an initial incidence of $0.4 \%$ in a vineyard where mealybug vector density was instead high, estimated average roguing and vine replacement increased to $c a .6 \%$ (150 vines) per year from Years 2 to 20 (Figs. $2 \mathrm{k}$ and $3 \mathrm{k}$ ). The increased focus on roguing and vine replacement substantially increased the cost of yield loss for replacement young vines. Thus, even at an initial incidence of $0.4 \%$, the influence of vector-mediated GLRaV-3 spread on roguing and yield loss from replacement vines meant estimated average costs plus loss of income was NZ\$4012 per year per hectare, which was a 31-fold increase relative to roguing where mealybug vector density was low (Table 3).

The model demonstrated that mealybug vector density was therefore a critical variable in determining the frequency and intensity of roguing and the planting of replacement vines. However, the problem was further compounded when initial virus incidence was higher than $0.4 \%$ (Figs. 2 and 3). For example, roguing at an initial 10, 15 and $20 \%$ incidence, a low vector density meant estimated average costs plus loss of income were NZ $\$ 506, \$ 726$ or $\$ 917$ per year per hectare, respectively (Table 3); at a high vector density, average costs plus loss of income increased substantially to NZ\$4766, $\$ 5144$ or $\$ 5457$ per year per hectare, respectively (Table 3). Independent of vector density and initial virus incidence, over $80 \%$ of the financial implication of roguing was attributed to vine removal and yield loss from replacement vines.

Comparing roguing with rogue $1+2$ In New Zealand, the idea that roguing might not adequately contain GLRaV-3 under some virus/vector circumstances was proposed, with rogue $1+2$ viewed as a possible alternative response. We tested the feasibility of rogue $1+2$ and compared the results with roguing.

At low and median mealybug vector densities, annual virus incidence ranged from 0.2 to $2 \%$ for the rogue and rogue $1+2$ responses, independent of initial virus incidence (Fig. 2a to j). At high mealybug vector densities, annual incidence for rogue $1+2$ was, on average, $5 \%$, which was marginally lower than for roguing (Fig. $2 \mathrm{k}$ to o). However, with an emphasis on removing symptomatic plus first vines concurrently, rogue $1+2$ generated an increased frequency of vine replacement when compared with roguing (Fig. 3a to o). Consequently, over $90 \%$ of the rogue $1+2$ costs were attributed to roguing and yield loss from young vines, while the equivalent costs for roguing were $82 \%$ (Table 3 ). For low and median mealybug vector densities, the estimated average annual costs plus loss of income for roguing was less than half that of rogue $1+2$, independent of initial virus incidence (Table 3). When mealybug vector density was high, both responses incurred increases to the estimated average annual incidence (Fig. $2 \mathrm{k}$ to o) and vine replacement (Fig. 3k to o). While severe financial implications were a feature of both responses at high vector densities (Table 3), estimated average annual costs plus loss of income for roguing was $c a .28 \%$ less per hectare than rogue $1+2$, independent of initial virus incidence.

Comparing roguing with inefficient roguing In our model, inefficient roguing was assumed to be the result of inadequate assessor training and/or visual assessments undertaken too early in the growing season to enable the identification of all GLRaV-3-symptomatic vines in a given year. The implication of both situations was that an assumed $50 \%$ of infected vines (or symptomless first vines) remained in situ for another 12 months, at least.

Roguing was a more effective management response than inefficient roguing (i.e. rogue $50 \%$, rogue $1+250 \%$ ), a result independent of initial virus incidence and mealybug vector densities. Where vector density was low, roguing resulted in average annual virus incidence typically less than $1 \%$ over 20 years, which was generally half that observed for inefficient roguing (Fig. 2a to e). However, where mealybug vector density was high, the implications of inadequate vector control were apparent for all three responses, with estimated average annual incidence of 8,10 , and $20 \%$ for roguing, rogue $1+250 \%$, and rogue 50\%, respectively (Fig. $2 \mathrm{k}$ to o). In turn, the planting of replacement vines increased where mealybug vector density was median (Fig. 3f to j) and high (Fig. 3k to o). The estimated average annual costs plus loss of income for each management response included the direct costs of roguing and yield loss from replacement young vines (Table 3). Additionally, both inefficient roguing responses incurred substantial costs related to yield loss from infected vines and lost crop value due to in situ infections (Table 3). Across the three mealybug vector densities tested, roguing was the better response than either inefficient option. However, as with all the management scenarios tested, costs continued to rise steeply as mealybug vector density increased. Therefore, even at an initial $0.4 \%$ GLRaV-3 incidence, high mealybug vector density generated estimated average annual costs plus loss of income for roguing and inefficient roguing that greatly exceeded those where mealybug vector density was either low or median (Table 3).

Comparing roguing with no-action Independent of mealybug vector density (low, median, or high), the management and cost implications of no-action against GLRaV-3 were consistently more severe than for roguing. For instance, at a low mealybug vector density and initial virus incidence of 0.4 and $20 \%$ (the two extremes used in the model), no-action resulted in estimated virus incidence of 6 and $40 \%$, respectively, after 20 years (Fig. 2a to e); at median vector density, an estimated 50 and $90 \%$ of vines, respectively, were infected after 20 years (Fig. $2 \mathrm{f}$ to j). At 
Table 3 Estimated average annual costs plus loss of income (New Zealand $\$$ values per hectare) in a simulated 1 ha Merlot vineyard affected by grapevine leafroll-associated virus 3 (GLRaV-3). Simulations over 20 years adopted five management responses (rogue, rogue $1+2$, rogue $50 \%$, rogue $1+250 \%$, no action) in the presence of low, median, and high numbers of mealybug vectors, when either $0.4,5$, 10,15 , and $20 \%$ of random Merlot vines were GLRaV-3-infected

\begin{tabular}{|c|c|c|c|c|c|c|c|c|c|c|c|c|c|c|c|}
\hline \multirow{2}{*}{$\begin{array}{l}\text { Breakdown of costs } \\
\text { Vector densities }\end{array}$} & \multicolumn{3}{|c|}{ Cost of roguing } & \multicolumn{3}{|c|}{$\begin{array}{l}\text { Cost of yield loss from } \\
\text { replacement young vines }\end{array}$} & \multicolumn{3}{|c|}{$\begin{array}{l}\text { Cost of lost yield due to } \\
\text { GLRaV-3 infections }\end{array}$} & \multicolumn{3}{|c|}{$\begin{array}{l}\text { Loss of crop value due to } \\
\text { GLRaV-3 infections }\end{array}$} & \multicolumn{3}{|c|}{ Sum of all costs } \\
\hline & Low $\dagger$ & Median & High & Low & Median & High & Low & Median & High & Low & Median & High & Low & Median & High \\
\hline$\%$ incidence & \multicolumn{15}{|c|}{ Management response - Roguing $\ddagger$} \\
\hline 0.4 & 56 & 277 & 1769 & 54 & 266 & 1660 & 21 & 104 & 582 & 0 & 0 & 0 & 131 & 647 & 4012 \\
\hline 5.0 & 132 & 367 & 1938 & 130 & 356 & 1827 & 48 & 135 & 632 & 0 & 0 & 0 & 310 & 858 & 4396 \\
\hline 10.0 & 214 & 465 & 2102 & 214 & 455 & 1987 & 78 & 169 & 678 & 0 & 0 & 0 & 506 & 1088 & 4766 \\
\hline 15.0 & 296 & 558 & 2259 & 296 & 548 & 2140 & 107 & 200 & 718 & 27 & 27 & 27 & 726 & 1333 & 5144 \\
\hline \multirow[t]{2}{*}{20.0} & 377 & 652 & 2391 & 378 & 642 & 2268 & 136 & 232 & 750 & 26 & 26 & 48 & 917 & 1551 & 5457 \\
\hline & \multicolumn{15}{|c|}{ Management response - Roguing $1+2$} \\
\hline 0.4 & 157 & 660 & 2741 & 152 & 625 & 2475 & 20 & 87 & 350 & 0 & 0 & 0 & 329 & 1372 & 5566 \\
\hline 5.0 & 366 & 882 & 3014 & 360 & 845 & 2732 & 47 & 113 & 377 & 0 & 0 & 0 & 773 & 1841 & 6122 \\
\hline 10.0 & 569 & 1096 & 3262 & 565 & 1056 & 2964 & 75 & 141 & 400 & 0 & 0 & 0 & 1208 & 2293 & 6626 \\
\hline 15.0 & 747 & 1282 & 3458 & 744 & 1240 & 3147 & 103 & 168 & 421 & 27 & 27 & 27 & 1621 & 2718 & 7053 \\
\hline \multirow[t]{2}{*}{20.0} & 904 & 1437 & 3646 & 902 & 1393 & 3324 & 130 & 195 & 446 & 26 & 26 & 26 & 1962 & 3050 & 7441 \\
\hline & \multicolumn{15}{|c|}{ Management response - Roguing $50 \%$} \\
\hline 0.4 & 55 & 326 & 2707 & 53 & 311 & 2501 & 37 & 216 & 1423 & 0 & 0 & 596 & 145 & 853 & 7227 \\
\hline 5.0 & 135 & 444 & 3048 & 133 & 429 & 2834 & 87 & 288 & 1569 & 0 & 0 & 815 & 355 & 1161 & 8266 \\
\hline 10.0 & 222 & 566 & 3336 & 221 & 552 & 3113 & 140 & 360 & 1679 & 0 & 0 & 988 & 582 & 1477 & 9116 \\
\hline 15.0 & 306 & 685 & 3564 & 306 & 671 & 3335 & 190 & 426 & 1762 & 27 & 27 & 1208 & 829 & 1809 & 9869 \\
\hline \multirow[t]{2}{*}{20.0} & 392 & 798 & 3744 & 392 & 784 & 3512 & 238 & 487 & 1823 & 26 & 51 & 1469 & 1049 & 2120 & 10,548 \\
\hline & \multicolumn{15}{|c|}{ Management response - Roguing $1+250 \%$} \\
\hline 0.4 & 152 & 687 & 3173 & 146 & 648 & 2848 & 35 & 161 & 666 & 0 & 0 & 0 & 332 & 1497 & 6688 \\
\hline 5.0 & 369 & 918 & 3534 & 362 & 877 & 3188 & 80 & 209 & 727 & 0 & 0 & 0 & 812 & 2004 & 7448 \\
\hline 10.0 & 563 & 1156 & 3851 & 556 & 1110 & 3480 & 121 & 257 & 773 & 0 & 0 & 0 & 1240 & 2523 & 8104 \\
\hline 15.0 & 754 & 1357 & 4109 & 744 & 1305 & 3717 & 160 & 295 & 811 & 27 & 27 & 66 & 1684 & 2984 & 8703 \\
\hline \multirow[t]{2}{*}{20.0} & 918 & 1528 & 4294 & 904 & 1469 & 3889 & 195 & 328 & 835 & 26 & 26 & 60 & 2042 & 3351 & 9079 \\
\hline & \multicolumn{15}{|c|}{ Management response - No-action } \\
\hline 0.4 & 0 & 0 & 0 & 0 & 0 & 0 & 203 & 1474 & 4510 & 0 & 1002 & 2427 & 203 & 2476 & 6937 \\
\hline 5.0 & 0 & 0 & 0 & 0 & 0 & 0 & 695 & 2448 & 5031 & 146 & 2026 & 2728 & 841 & 4473 & 7759 \\
\hline 10.0 & 0 & 0 & 0 & 0 & 0 & 0 & 1190 & 3178 & 5378 & 454 & 2681 & 2858 & 1644 & 5858 & 8236 \\
\hline 15.0 & 0 & 0 & 0 & 0 & 0 & 0 & 1650 & 3741 & 5610 & 1399 & 2966 & 2962 & 3050 & 6707 & 8628 \\
\hline 20.0 & 0 & 0 & 0 & 0 & 0 & 0 & 2093 & 4179 & 5780 & 2090 & 3143 & 3017 & 4183 & 7321 & 8742 \\
\hline
\end{tabular}

${ }^{\dagger}$ Low mealybug vector density $=6$ P. calceolariae per 100 vine leaves; median vector density $=26$ P. calceolariae per 100 vine leaves; high vector density $=75$ P. calceolariae per 100 vine leaves

${ }^{\star}$ Rogue = removing all GLRaV-3-infected vines each year and planting healthy replacement vines; Rogue $1+2=$ removing and replanting the GLRaV3 -symptomatic vine plus the adjacent within-row (or 'first') vines either side of it; Rogue 50\% = roguing a random 50\% of GLRaV-3-infected vines each year, and Rogue $1+250 \%=$ roguing a random $50 \%$ of GLRaV-3-infected vines and the first vines each year, with both inefficient responses assumed to occur where vineyard personnel were insufficiently trained to recognise GLRaV-3 symptoms and/or where visual diagnostics were undertaken too early in the growing season to identify all vines likely to show foliar symptoms in a given year; No action = a decision not to rogue any GLRaV-3-infected vines

a high vector density and initial virus incidence of 0.4 and $20 \%, 90 \%$ of vines were infected after an estimated 13 and 8 years, respectively (Fig. $2 \mathrm{k}$ to o). By comparison, roguing when mealybug vector density was low (Fig. 2a to e) and median (Fig. $2 \mathrm{f}$ to $\mathrm{j}$ ), resulted in an estimated average annual incidence of $<1 \%$ over 20 years; at a high vector density, it never exceeded $10 \%$ (Fig. $2 \mathrm{k}$ to o). Rather than no-action incurring the direct costs of roguing and vine replacement, all costs were instead attributed to yield loss from the infected vines and the loss of crop 


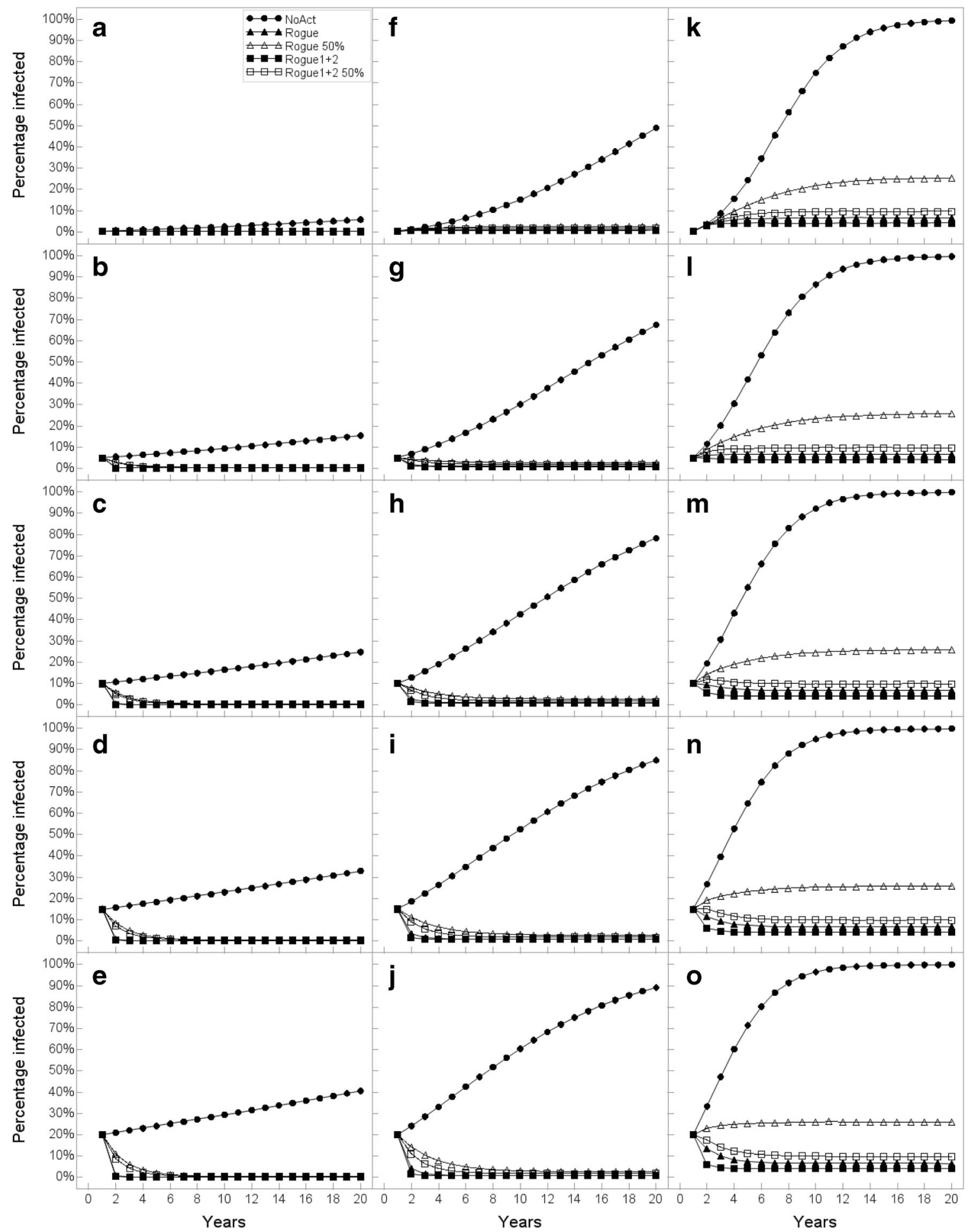

Fig. 2 Estimated annual incidence of grapevine leafroll-associated virus 3 -infected Merlot vines over a 20 year timeline following the adoption of roguing, roguing $1+2$, roguing $50 \%$, roguing $1+250 \%$, or no action
(NoAct) at an initial incidence of $0.4(\mathbf{a}, \mathbf{f}, \mathbf{k}), 5(\mathbf{b}, \mathbf{g}, \mathbf{l}), 10(\mathbf{c}, \mathbf{h}, \mathbf{m}), 15$ $(\mathbf{d}, \mathbf{i}, \mathbf{n})$, and $20 \%$ (e, $\mathbf{j}, \mathbf{o})$, when vector density was either low (a to e), median (f to $\mathbf{j})$, or high (k to $\mathbf{o}$ )

\section{Discussion}

In having modelled the relationship between GLRaV-3 incidence and mealybug vector density, our objective was to determine an optimal vine removal response based 


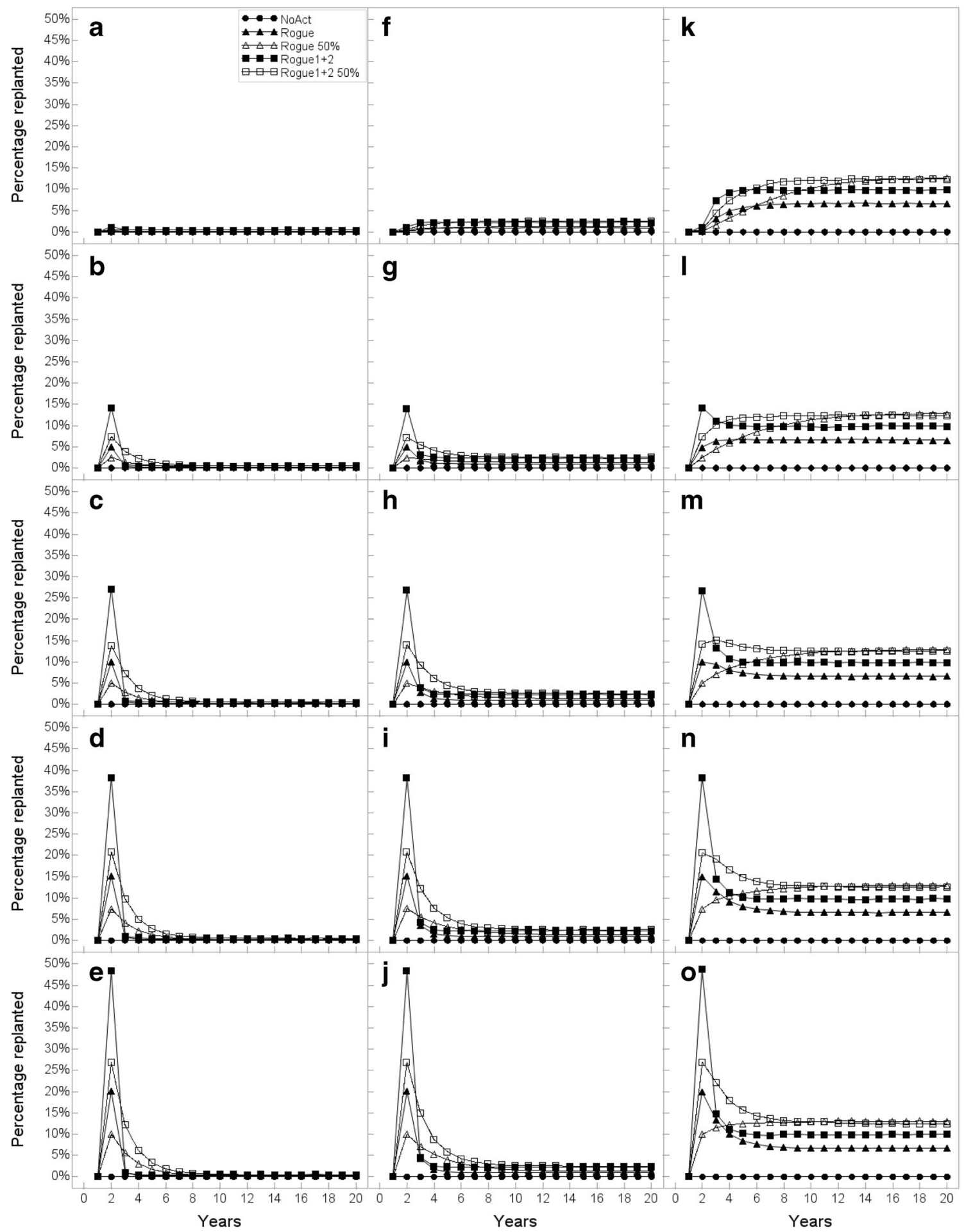

Fig. 3 Estimated percentage of replacement Merlot vines planted annually over 20 years, when managing grapevine leafroll-associated virus 3 , either by roguing, roguing $1+2$, roguing $50 \%$, roguing $1+2$

on differing virus/vector scenarios likely to be found in New Zealand vineyards. Whilst continuing to reiterate the negative implications of a no-action decision and inefficient roguing, we anticipated these analyses would also generate new insights to better define circumstances that
$50 \%$, or no action (NoAct) at an initial incidence of $0.4(\mathbf{a}, \mathbf{f}, \mathbf{k}), 5$ (b, $\mathbf{g}, \mathbf{l}), 10(\mathbf{c}, \mathbf{h}, \mathbf{m}), 15(\mathbf{d}, \mathbf{i}, \mathbf{n})$, and $20 \%$ (e, j, o), and when vector density was either low (a to e e), median (f to $\mathbf{j}$ ), or high (k to o)

could warrant modification to the current roguing response.

From our model, however, roguing optimised GLRaV-3 management outcomes, independent of the initial virus incidence and the mealybug vector densities tested. Roguing 
typically incurred the lowest annual virus incidence, the least need to plant replacement vines and the lowest estimated average annual costs plus loss of income. These findings vindicated the current recommendation promulgated by New Zealand Winegrowers, whereby only vines with foliar symptoms of GLRaV-3 are rogued annually (Andrew et al. 2015). Indeed, the positive virus management outcomes observed in several of the Bell et al. (2018) study vineyards supported many of the predictions by Sisterson and Stenger (2013). Specifically, the model demonstrated that in targeting GLRaV-3 early when incidence was low (0.4-5\%), control was achieved relatively quickly. Even where initial virus incidence was moderate to high (10-20\%), roguing minimised annual incidence, reduced the frequency of vine replacement and was the most cost-effective management response relative to the other responses tested.

While the outcomes of virus management were positively influenced by roguing, the results of our model were inextricably linked to mealybug vector density. In particular, the model estimated that when vector density was low (six $P$. calceolariae per 100 vine leaves), average annual virus incidence and planting replacement vines quickly reduced to $<1.0 \%$ until Year 20, irrespective of initial virus incidence. Thus, under these conditions, roguing culminated in estimated average annual costs plus loss of income ranging from $\mathrm{NZ} \$ 131$ per hectare at $0.4 \%$ incidence to NZ\$917 per hectare at $20 \%$. By contrast, where mealybug vector density was high (75 P. calceolariae per 100 vine leaves), roguing resulted in estimated average annual virus incidence and annual vine planting of $c a .8 \%$, with estimated average annual costs plus loss of income over four-fold higher increasing to NZ\$4012 $(0.4 \%)$ and NZ\$5457 (20\%) per hectare. Thus, for GLRaV-3, the model demonstrated that the success of roguing was reliant upon mealybug vector control reducing the risk of secondary pathogen spread, as noted by Sisterson and Stenger (2013).

We also evaluated rogue $1+2$ (concurrent roguing of symptomatic plus both within-row neighbouring vines) to determine the feasibility of acting pre-emptively against GLRaV-3 under some circumstances. The results were compared with roguing. The model showed that estimated average annual virus incidence was marginally lower for roguing $1+2$ than for roguing, a result most evident where mealybug vector density was high. One explanation for this result was the likelihood that an estimated 12-month GLRaV-3 latent period among a proportion of first vines meant they were preemptively removed before foliar symptoms appeared and thus before they could be included in annual incidence calculations using visual diagnostics. In other words, the model may have under-estimated annual incidence in rogue $1+2$, possibly by as much as 1 percentage point, depending on mealybug vector density. However, after factoring in the direct costs of roguing and the cost of yield loss from replacement vines, the estimated average annual costs plus loss of income for roguing was at least half that of rogue $1+2$, independent of initial virus incidence. Therefore, the importance of adopting an effective integrated management response, including good vector control, was again demonstrated. Moreover, it was apparent there were no virus/vector scenarios tested where rogue $1+2$ would preferentially replace roguing whilst delivering better GLRaV-3 management outcomes with few negative financial implications. Thus, any future implementation of rogue $1+2$ is most likely to be predicated upon the particular circumstances and preferences of individual vineyard owners.

Our work also highlighted other results likely to inform future decisions about GLRaV-3 management.

This study showed that inefficient roguing (i.e. rogue $50 \%$, rogue $1+250 \%$ ) did not manage GLRaV-3 effectively. As a result, estimated average annual costs plus loss of income were high relative to roguing and also for a no-action response (where mealybug numbers were high). Both inefficient responses were approximately comparable with two values for plant replacement used by Sisterson and Stenger (2013) specifically with $R=0.25$ and $R=0.50$, where infected plants were not rogued and remained in situ for an average of 4 and 2 years, respectively. In our model, we assumed inefficient roguing was the result of inadequate assessor training and/or poorly timed visual inspections, meaning $50 \%$ of symptomatic vines (or symptomless first vines) remained in situ for at least another 12 months. In New Zealand, visual inspections for GLRaV-3 generally occur post-harvest, which offers assessors the best opportunity to identify most, if not all, symptomatic vines in a given year (Bell et al. 2015). But this outcome relies on trained assessors able to visually differentiate GLRaV-3-infected vines reliably from those with similar foliar symptoms for unrelated and generally benign conditions like cane girdling or mineral deficiencies. Furthermore, competent assessors reduce the likelihood of healthy vines being unnecessarily removed because of over-estimating GLRaV-3 incidence (false positives) or of under-estimating it (false negatives) by missing vines with rudimentary GLRaV-3 foliar symptoms (see Bell et al. 2017). Once identified, the model showed that the efficient, annual removal of all symptomatic vines greatly reduced the risk of vector-mediated disease spread. While this outcome was predicted by Sisterson and Stenger (2013), the results were corroborated by Pietersen et al. (2013, 2017) and Bell et al. (2018) during their multiyear assessments in commercial vineyards undertaking roguing.

Likewise, the decision not to act to manage GLRaV-3 up to the maximum $20 \%$ incidence contributed to multiple negative outcomes relative to roguing. One indicator from this study that will be readily understood by all owners is the substantial increase in the estimated average annual costs plus loss of income per hectare for a no-action decision. Further reinforcing the negative implications of no action were rapid increases in annual and cumulative virus incidence and thus the 
relatively short interval before more than $50 \%$ of vines were infected. Consequently, for those owners choosing to do nothing to manage GLRaV-3, any perceived advantage of not incurring the direct costs of roguing and planting replacement vines would be quickly negated by factors like yield loss from infected vines or devalued crop due to the imposition of a quality penalty (Ricketts et al. 2015).

In conclusion, the model showed that up to the maximum $20 \%$ initial GLRaV-3 incidence, annually roguing only those vines with foliar symptoms optimised management outcomes in commercial vineyards in New Zealand. However, while roguing was the optimal response relative to the others tested, the outcomes of GLRaV-3 management were vector density dependent. Hence, for vineyards affected by GLRaV-3, the foundation for economic sustainability not only requires that roguing be efficient but that it be supported by vector management that is effective.

Supplementary Information The online version contains supplementary material available at https://doi.org/10.1007/s42161-020-00736-7.

Acknowledgements We gratefully acknowledge joint funding for this research from the Ministry of Business, Innovation and Employment and New Zealand Winegrowers Research Centre Limited (NZWRC), Blenheim, New Zealand. We would like to acknowledge the support of Simon Hooker, Will Kerner, and Nick Hoskins (all of NZWRC). We thank two anonymous reviewers for their helpful comments, and Duncan Hedderley and Andrew McLachlan (both of Plant and Food Research) for reviewing an earlier version of this manuscript. Finally, we are grateful for the support of the vineyard owners and viticulture personnel who allowed us to access their properties over multiple years.

\section{Compliance with ethical standards}

Conflicts of interest All authors are unaware of any conflicts of interest or competing interests likely to affect publication of this research; Data availability - the data presented in this paper are owned by New Zealand Winegrowers Research Centre Limited.

\section{References}

Almeida RPP, Daane KM, Bell VA, Blaisdell GK, Cooper ML, Herrbach E, Pietersen G (2013) Ecology and management of grapevine leafroll disease. Front Microbiol 4(94):1-13
Andrew R, Bell V, Hoskins N, Pietersen G, Thompson C (eds) (2015) Leafroll 3 virus and how to manage it. New Zealand Winegrowers. Auckland, New Zealand

Atallah SS, Gomez MI, Fuchs MF, Martinson TE (2012) Economic impact of Grapevine leafroll disease on Vitis vinifera cv. Cabernet franc in Finger Lakes vineyards of New York. Am J Enol Vitic 63:73-79

Bell VA, Chooi KM, Blouin AG, Cohen D, Pietersen G, MacDiarmid R (2015) GLRaV-3 in New Zealand: biological impact and timing of the symptoms influences on the management strategies. 18th Congress of the International Council for the Study of Virus and Virus-like Diseases of the Grapevine (ICVG), Ankara, Turkey, 7-11 September 2015

Bell VA, Blouin AG, Cohen D, Hedderley DI, Oosthuisen T, Spreeth N, Lester PJ, Pietersen G (2017) Visual symptom identification of Grapevine leafroll-associated virus 3 in red berry cultivars supports virus management by roguing. J Plant Pathol 99(2):477-482

Bell VA, Hedderley DI, Pietersen G, Lester PJ (2018) Vineyard-wide control of Grapevine leafroll-associated virus 3 requires an integrated response. J Plant Pathol 100(3):399-408

Golino D, Sim ST, Gill R, Rowhani A (2002) California mealybugs can spread grapevine leafroll disease. Calif Agric 56:196-201

Maree HJ, Almeida RPP, Bester R, Chooi K, Cohen D, Dolja VV, Fuchs MF, Golino DA, Jooste AEC, Martelli GP, Naidu RA, Rowhani A, Saldarelli P, Burger JT (2013) Grapevine leafroll-associated virus 3. Front Microbiol 4:82

Nimmo-Bell \& Company Limited (2006) The Economic effects and financial impacts of GLRaV3. Report for New Zealand Winegrowers, Auckland, New Zealand

Petersen CL, Charles JG (1997) Transmission of grapevine leafrollassociated virus closteroviruses by Pseudococcus longispinus and P. calceolariae. Plant Pathol 46:509-515

Pietersen G, Spreeth N, Oosthuizen T, van Rensberg A, van Rensberg M, Lottering D, Rossouw N, Tooth D (2013) Control of grapevine leafroll disease spread at a commercial wine estate in South Africa: a case study. Am J Enol Vitic 64:296-305

Pietersen G, Bell VA, Krüger K (2017) Management of Grapevine Leafroll Disease and Associated Vectors in Vineyards. In: Meng B, Martelli GP (eds) Grapevine Viruses: Molecular Biology, Diagnostics and Management. Fuchs M. Springer International Publishing, Golino DA, pp 531-560

Ricketts KD, Gomez MI, Atallah SS, Fuchs MF, Martinson TE, Battany MC, Bettinga LJ, Cooper ML, Verdegaal PS, Smith RJ (2015) Reducing the economic impact of grapevine leafroll disease in California: identifying optimal disease management strategies. Am J Enol Vitic 66:138-147

Sisterson MS, Stenger DC (2013) Roguing with replacement in perennial crops: conditions for successful disease management. Phytopathology 103:117-128

Publisher's note Springer Nature remains neutral with regard to jurisdictional claims in published maps and institutional affiliations. 